\begin{tabular}{|l|l|c|l|}
\hline Eiszeitalter u. Gegenwart & $\mathbf{4 8}$ & $177-191$ & Hannover 1998 \\
\hline
\end{tabular}

\title{
Evolution of Lamayuru palaeolake in the Trans Himalaya: Palaeoecological implications
}

\author{
Bahadur Singh Kotlia, Ingelore Hinz-Schallreuter, Roger Schallreuter \& Jürgen Schwarz*) \\ Palaeolake deposits, neotectonics, Lamayuru (Ladakh), Late Pleistocene, \\ fossils, palaeoecology
}

\begin{abstract}
About 35,000-40,000 yr BP, an episode of neotectonic activity on the Indus Suture Zone created a lake at Lamayuru (Ladakh) that has preserved an over $105 \mathrm{~m}$ thick sequence of fluvio-lacustrine deposits. The lacustrine horizons (carbonaceous muds) and a number of carbonate-rich strata interlayered with clay/ silt/sand have yielded freshwater ostracods, gastropods and charophytes. A total of nine fossiliferous horizons are located. The prominent ostracod taxa are llyocypris (I. gibba and I. bradyi), Eucypris and Candona. The gastropods are dominated by Lymnaea, Succinea and Gyraulus. The charophytes can be identified as Chara globularis. The palaeoecological interpretation is based on the characteristic faunal and floral content and the nature of deposits. It is suggested that the lake, throughout its existence, was shallow with cold, extremely low salinity and slow flowing plant-rich waters. As an open basin, it may have had continuous outflow during its existence. The depletion of the lake was caused by structural disruption of the lake floor and by deposition of a huge mass of debris flow, triggered by a further pulse of tectonic instability in the Late Holocene.
\end{abstract}

\section{[Entwicklung des Lamayuru-Paläosees im Trans- Himalaya: Paläoökologische Bedeutung]}

Kurzfassung: Vor etwa 35 000-40 000 Jahren schuf eine Episode neotektonischer Aktivität an der Indus-Sutur bei Lamayuru (Ladakh) einen See, von dem eine über $105 \mathrm{~m}$ mächtige Abfolge fluviolakustriner Ablagerungen erhalten ist. Die zwischen Ton/Silt/Sand eingelagerten lakustrinen Horizonte (Kalkschlämme) und karbonatreichen Schichten haben Süßwasser-Ostrakoden, Gastropoden und Charophyten geliefert. Insgesamt wurden 9 Fossilhorizonte angetroffen. Die hauptsächlichen Ostrakodentaxa sind llyocypris (l. gibba und l. bradyi), Eucypris und Candona. Bei den Gastropoden dominieren Lymnaea, Succineaund Gyraulus. Die Charophyten werden durch Chara globularis vertreten. Die paläoökologische Interpretation basiert auf den charakteristischen Faunen- und Florenelementen und auf der Natur der Sedimente. Es wird vermutet, daß der See während seiner ganzen Existenz ziemlich flach war und kaltes,

*) Addresses of Authors: Dr. B. S. KotliA, Department of Geology, Durham House, Kumaun University, Nainital (U.P.), 263 002, India; PD Dr. I. Hinz-SCHALlREuTER, Museum für Naturkunde, Invalidenstr. 43, D-10115 Berlin, Germany; PD Dr. R. Schallreuter, GeologischPaläontologisches Institut und Museum, Bundesstr. 55, D-20146 Hamburg, Germany; Dr. J. ScHwarz, Habsburgerallee 106, D-60385, Frankfurt am Main, Germany extrem salzarmes, langsam fließendes, pflanzenreiches Wasser führte. Als ein offenes Becken mag er einen kontinuierlichen Abfluß während seiner ganzen Existenz gehabt haben. Die Entleerung des Sees wurde verursacht durch eine strukturelle Zerrüttung des Seebodens und die Ausfüllung durch riesige, durch einen weiteren Impuls tektonischer Aktivität ausgelöste Schuttmassen.

\section{Introduction}

Northward movement of the Indian plate has caused accumulation of stress which is periodically released and results in the tectonic activity along the major faults/thrusts/tectonic zones (NAKATA, 1975). The Quaternary time witnessed the intense orogenic movements in the Himalaya (GeE, 1989). Such movements, episodic in nature, especially during the Pliocene-Quaternary Period, have been responsible for complex architecture of the Himalaya. The Himalayan mountains of northern Pakistan have experienced probably world's most active uplifts and records of Quaternary basins (SHRODER et al., 1989). Around 1.5 ma BP, major uplifting and thrusting occurred in the Salt Range, northwest Himalaya and the thrusting was also active in near regions (BuTLER et al., 1987; BurBank \& BeCK, 1989). A number of Himalayan sedimentary basins, such as Peshawar (Burbank, 1983), Kashmir (Burbank \& Johnson, 1982; Agrawal et al., 1989; Holmes et al., 1992), Kumaun (KotLia et al., 1997a) and Kathmandu (ForT, 1980) have evolved during the Plio-Pleistocene as a result of tectonic movements, and are still experiencing continued tectonism. Similarly, in Ladakh Himalaya, the Indus Suture Zone represents one of the most spectacular tectonic zones of the globe (GANSSER, 1964, 1977; Frank et al., 1977; SRIKANTIA \& RAZDAN, 1980; THAKuR, 1981). Northward, the uplifts along Nanga Parbat-Haramosh syntaxis and along northeastern margin of the Himalayan seismic zones have contributed to the ponding of the Indus river in the Skardu basin (Cronin, 1989).

During the Upper Quaternary, reactivations of major thrusts/faults in a number of Himalayan sectors have produced an enormous amount of debris avalanches resulting from slope failures and these have caused a blockade of ancient drainages and 
formation of palaeolake basins (BURBANK, 1983; VALDIYA et al., 1992; KotLia et al., 1997a). In the tectonically and seismically active Himalayan domain, such slope failures and impoundment of rivers are very common (CRONIN, 1982, 1987; VALDIYA et al., 1992, 1996). Similarly, the Indus Suture Zone in the Trans-Himalaya has also been considered as tectonically active during the Quaternary period (KoTLIA et al., 1997b). A number of palaeolakes formed by damming of ancient drainages in Ladakh in the northern Himalayan crest (e.g., at Skardu, Cronin, 1982, 1989; at Jalipur on the Indus river, SHroder et al., 1986, at Khaltse and along Gilgit river, BüRGISSER et al., 1982; in the upper Indus valley, OwEN, 1988) and at Lamayuru (ForT et al., 1989; SANGODE \& BAGATI et al., 1996; KotLia et al., 1997b) resulted from a reactivation of this zone in the Late Pleistocene. In western Ladakh (Fig. 1a), at an altitude of $3600 \mathrm{~m}$, a lake was formed by damming of the River Lamayuru (a tributary of Indus) as a result of tectonic upheaval on the Indus Suture Zone in the Late Pleistocene. The spectacular lake deposits (Fig. 2) are locally called "Moonland rocks". Contemporary to the Lamayuru lake, another lake (we shall call it Pitok lake) was formed at Leh (Fig. 3) due to damming of the Indus river. About $10-11 \mathrm{~km}$ in length and 3-4 $\mathrm{km}$ in width, Pitok palaeolake deposits, exposed by the modern Indus at an altitude of about $3090 \mathrm{~m}$ are under study.

The neotectonic movements around Lamayuru are evidenced by various geomorphic features, such as the formation of river terraces developed along the Lamayuru and Indus rivers, the modification of drainage including steep waterfalls on the western side of the Lamayuru village, the nature of lineament running parallel to the Lamayuru river, the formation of gorge ( $600 \mathrm{~m}$ deep) and entrenched meanders within the course of the river. Extensive shattering, crushing and weathering of the country rocks at the contact of overlying lake deposits, and soft sedimentary deformational structures (e.g., micro-faulting, composite contortions, anticlinal/ synclinal features) within the basalmost part of the palaeolake profile (Fig. 4) may further indicate the tectonic activity at the time of formation of the lake. Although similar deformational structures are also related to seismic or glacial processes, a variety of geomorphological features as mentioned in the text, favour neotectonic processes in the Lamayuru valley.

The lacustrine muds, strata rich in biogenic activity and rapidly filled clastic deposits form the bulk of the fuvio-lacustrine profile (Fig. 1c) at Lamayuru. A further episode of neotectonic activity, a sudden pulse of which was responsible for depositing a very thick (ca. 25-50 m) debris flow from the steep adjacent slopes may have caused breaching of the dam. The debris flow is characterised by highly angular and ill-sorted pebbles to granules with sandy/muddy matrix and periglacial detritus. Although a precise date for this tectonic activity is not known, it may have occurred about 1,000 yr BP (Bürgisser et al., 1982; ForT et al., 1989). Out of the two levels of prominent terraces exposed along the Indus river between Khaltse and Leh, the younger terrace which is composed of river terrace deposits with rounded to angular gravels and clay/sand and with abundant matrix appears to be synchronous with this event.

\section{Lithology and Age of Deposits}

The basalmost part $(5-10 \mathrm{~cm}$ thick $)$ is a mixture of crushed and weathered country rocks and carbonaceous mud. The whole litho-sequence can be divided into four major lithological units. The lower part (0-13 m) is composed mainly of upward coarsening cycles of organic rich lacustrine muds/clays/silty clays and fine sands. The deposit between $13-45 \mathrm{~m}$ is dominated by recurring cycles of silty muds and medium sands, interbedded with numerous $\mathrm{mm}-\mathrm{cm}$ scale carbonate layers or lenses and a few thick carbonate beds. Excellent preservation of plant remains, e.g., fragile leaves, stems, twigs and seeds, also characterises this lithological unit. Between 45 and 75 m, medium-coarse sands showing cross and flaser beddings are dominant. Although not frequently, carbonate layers/horizons are also found in this unit. The uppermost part of the sequence is characterised by colluvial deposit of poorly sorted debris flow with several lenses of coarse sand and occasional clay lenses. Although there are plenty of carbonate-rich strata throughout the section, major and thick (up to 70 $\mathrm{cm}$ ) horizons are at 36, 57, 64 and $72 \mathrm{~m}$ levels.

A gastropod-rich horizon, dated 35,000 yr BP by FORT et al. (1989) is close to the top of the basalmost mud in our section (see Fig. 1c). A further carbonaceous horizon, dated 25,500 yr BP (FORT et al., 1989) seems to be correlatable with a deposit about $5 \mathrm{~m}$ above the base in our section. BAGATI et al. (1996) dated a charcoal-rich mud at Rong Gonghka locality of 40,000 yr BP and suggested a little older date for the basalmost beds. We have obtained an age of 22,000 yr BP on a charcoal-rich carbonaceous mud at $5.3 \mathrm{~m}$ level in the section (age according to G. RAJAGOPALAN, Radiocarbon Laboratory, BSIP, Lucknow, India). On the basis of these 

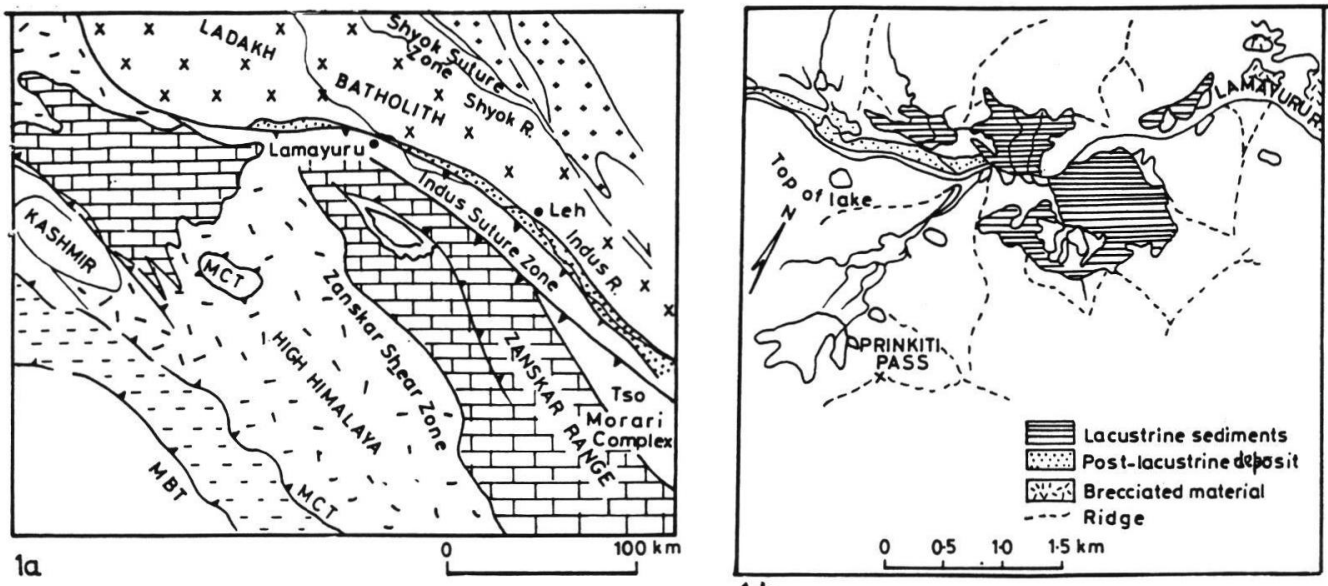

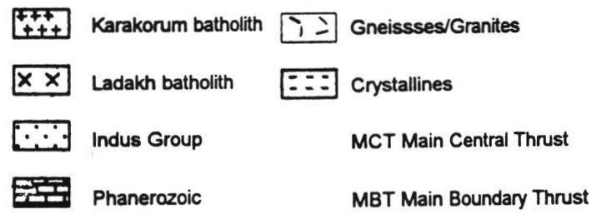

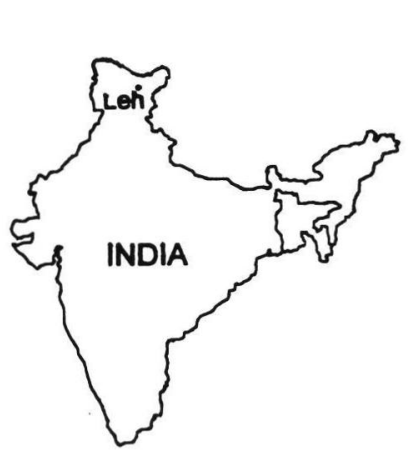

LEGEND for $1 \mathrm{c}$

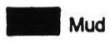

正 clay

Fine sand

$\because \because:$ Medium sand

Silty Clay

$\because+?$ Carbonate rich bed

뭉. Breccia

$x x x$ Fossil horizon

S5s Bioturbation

1. Charcoal

IVIV Cross bedding

II Current ripples

A Wave ripples

돌 Horizontal lamminations

Deformation features

$1 \mathrm{~b}$

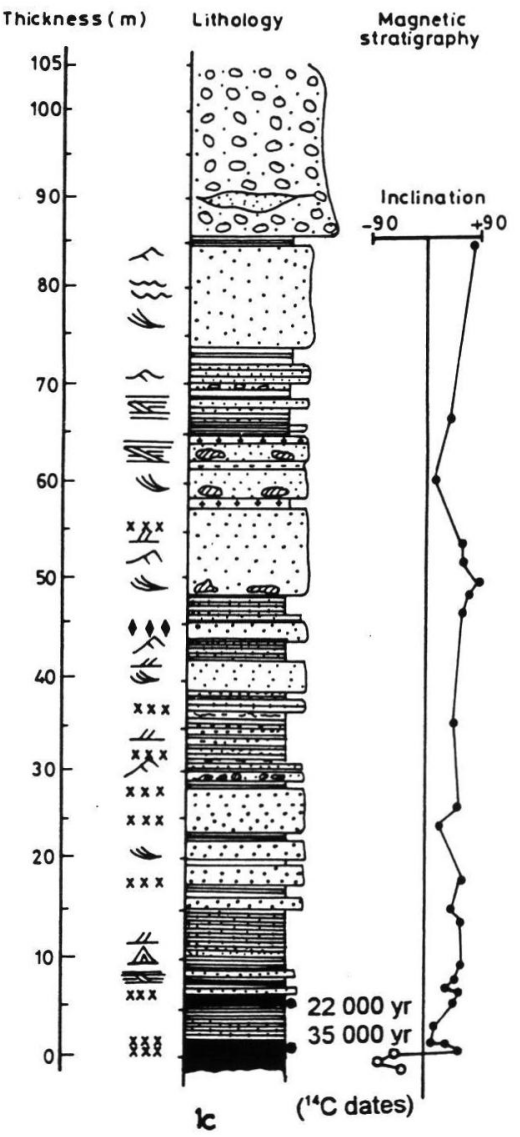

Fig. 1: a) Geological map around Lamayuru (simplified from SHRODER et al., 1989).

b) Extent of Lamayuru palaeolake (simplified from ForT et al., 1989.

c) Lithocolum of the profile showing fossiliferous horizons (magnetostratigraphy after KoTLIA et al., 1997b).

Abb. 1: a) Geologische Übersichtskarte der Umgebung von Lamayuru (vereinfacht nach ScHroner et al., 1989).

b) Ausdehnung des Lamayuru-Paläosees (vereinfacht nach ForT et al., 1989).

c) Lithologie des Profils und Lage der fossilführenden Horizonte (Magnetostratigraphie nach KotLIA et al., 1997b) 


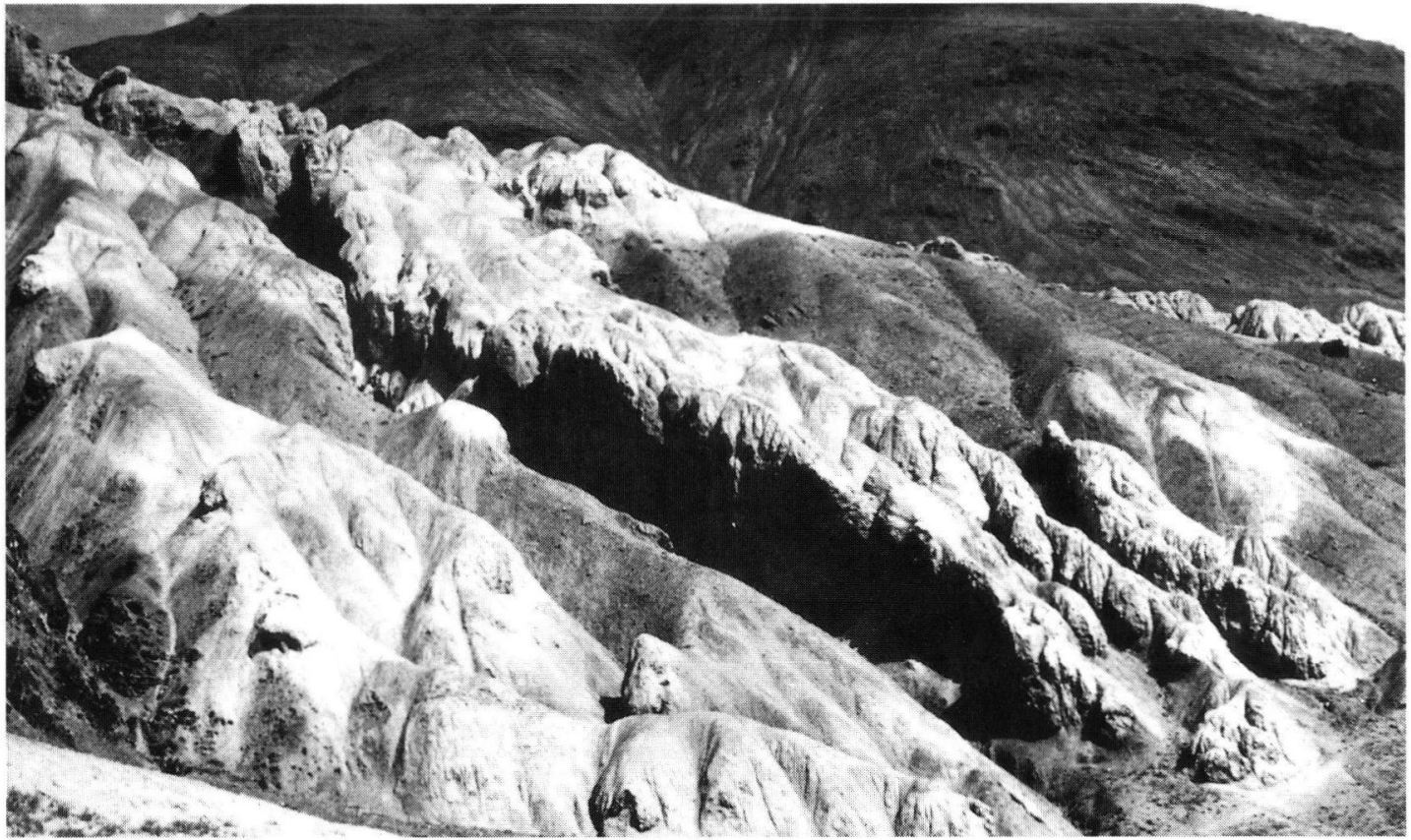

Figure 2: Quaternary deposits at Lamayuru.

Abb. 2: Quartäre Ablagerungen in der Umgebung von Lamayuru.

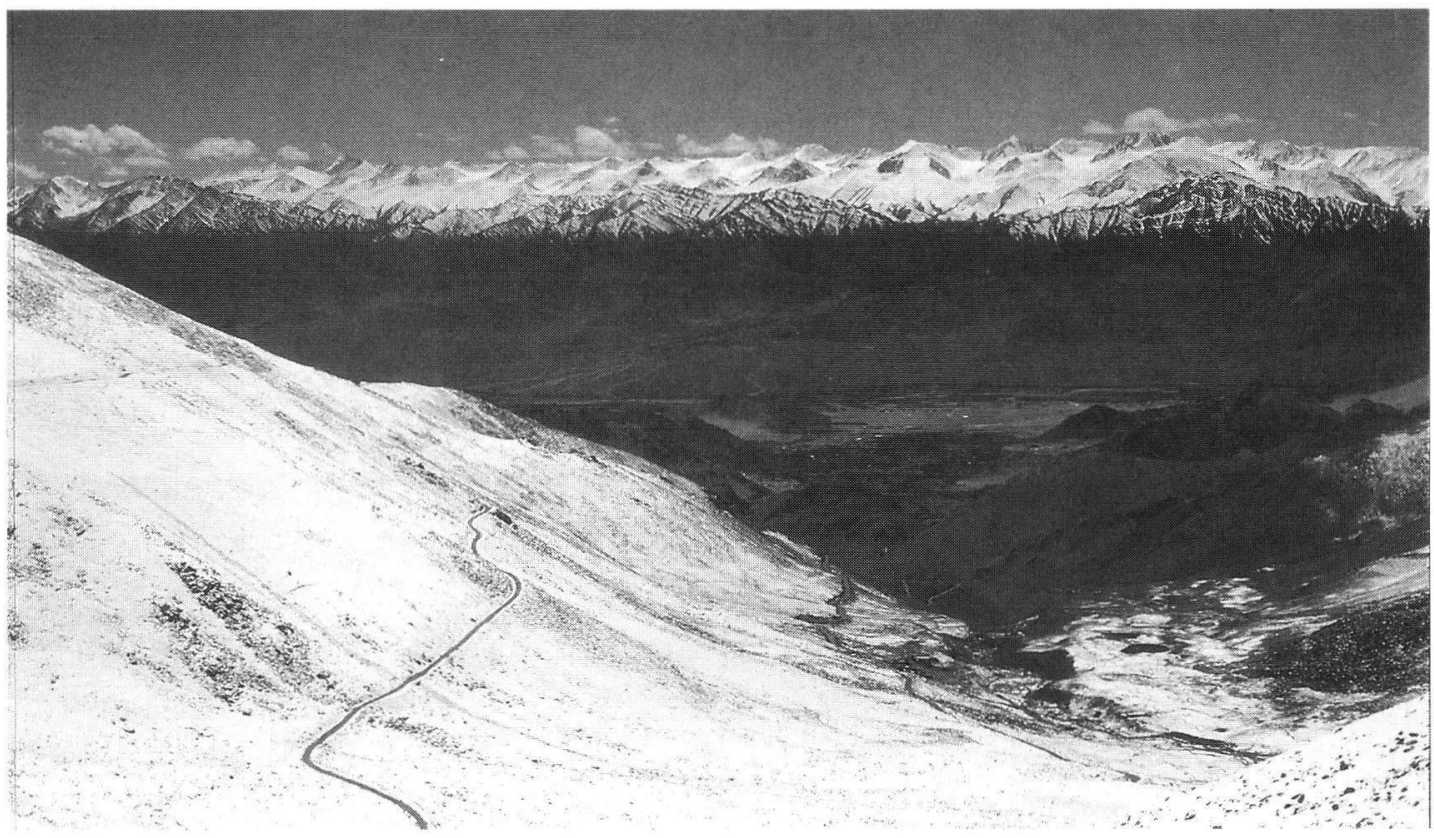

Figure 3: Leh (Ladakh) Quaternary deposits in the Vally (The road is leading to Khardungla, the highest pass of the world).

Abb. 3: Leh (Ladakh) Quartäre Ablagerungen im Tal (Die Straße führt nach Khardungla, dem höchsten Paß der Welt).

these dates, it is not realistic to assume the sedimentation rate because of varied sedimentation pattern throughout the sequence.
A detailed palaeomagnetic chronology of the sequence was carried out by KotLia et al. (1998) who reported a magnetic reversal at the base (see 


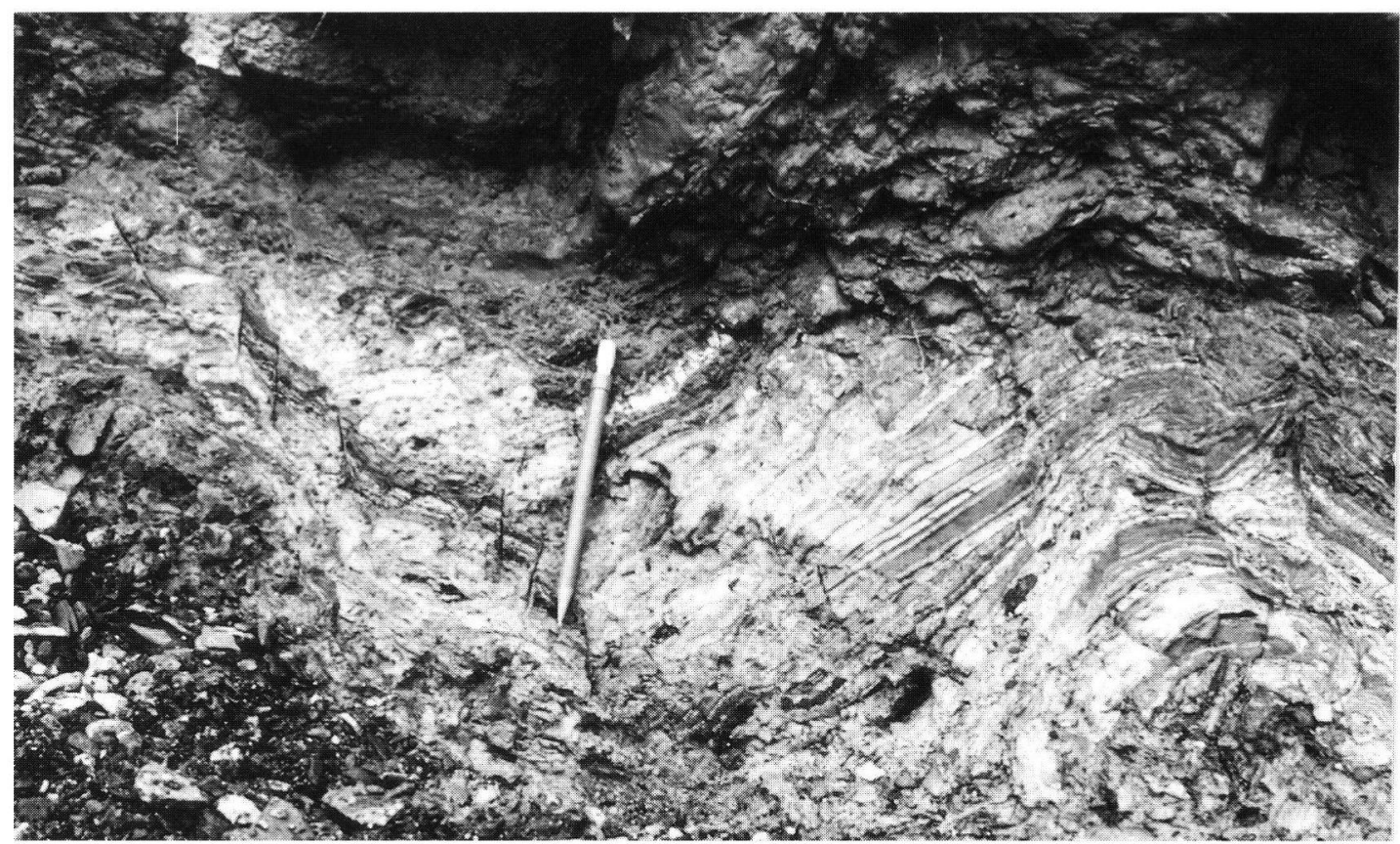

Figure 4: Soft deformational structures in the basalmost part in the sequence.

Abb. 4: Verformungs-Strukturen im allertiefsten Bereich der Abfolge.
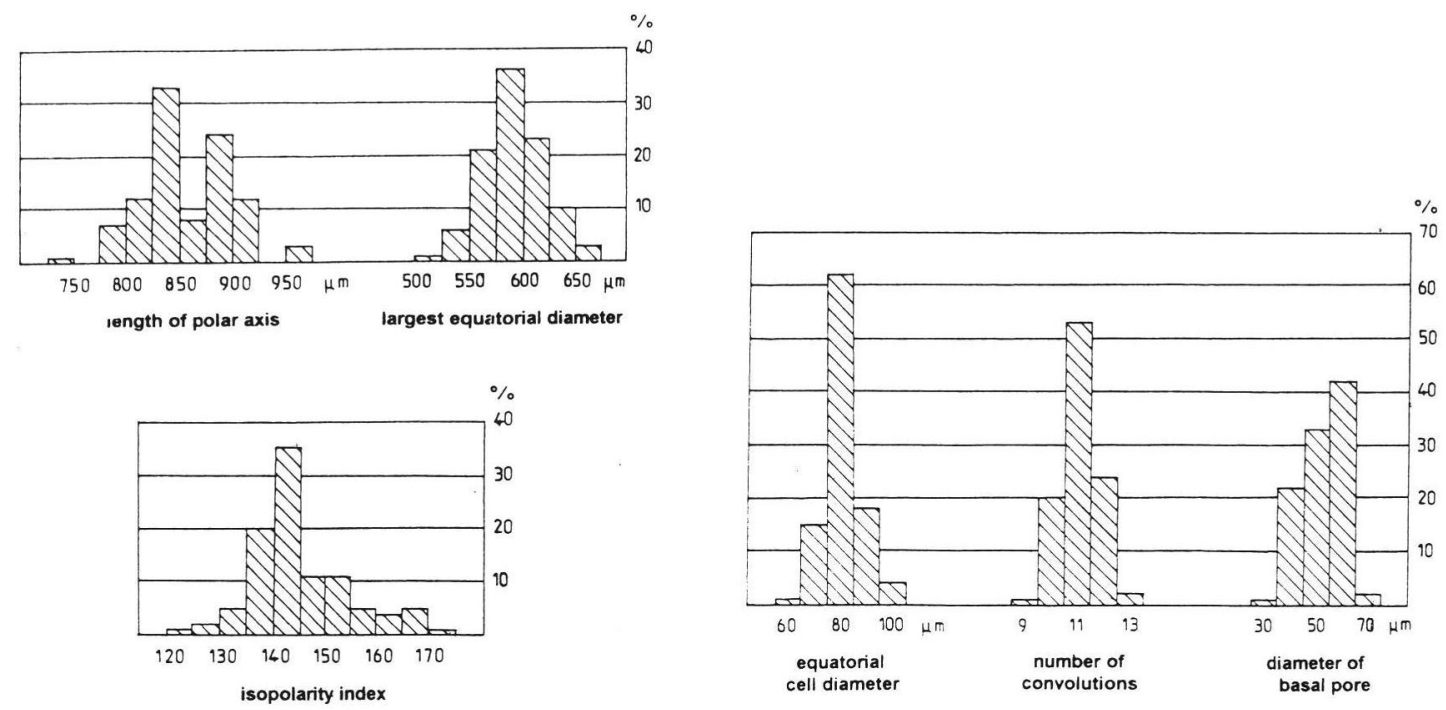

Figure 5: Chara globularis; histograms of some parameters, measured on 100 gyrogonites from MV4 horizon in the sequence.

Abb. 5: Chara globularis, Histogramme einiger Parameter, ermittelt an 100 Gyrogoniten aus dem Horizont MV 4 innerhalb der Abfolge.

Fig. 1c). Prior to this work, the only known magnetic reversal event within the upper Quaternary in south Asia around this time from Indian Ocean sediments has been dated to 40,000 yr BP (OPDYKE et al., 1974), and both the Lamayuru and Indian
Ocean events are correlatable (KoTLIA et al., 1998). Thus, the available data suggest that the initiation of lacustrine sedimentation at Lamayuru took place around 35,000-40,000 yr BP, and that the fossil horizons, MV3-MV9 are younger than 22,000 yr 
Table 1: Lithology of various fossil horizons and recovered fossils.

Tab. 1: Lithologie der fossilführenden Horizonte und registrierte Fossilien.

\begin{tabular}{|c|c|c|c|c|c|}
\hline \multirow{2}{*}{$\begin{array}{l}\text { Hori- } \\
\text { zon }\end{array}$} & \multirow{2}{*}{$\begin{array}{l}\text { Heigh } \\
\text { from base }\end{array}$} & \multirow[t]{2}{*}{ Lithology } & \multicolumn{2}{|c|}{ Invertebrate fossils } & \multirow[t]{2}{*}{ Charophytes } \\
\hline & & & Ostracods & tropods & \\
\hline MV1 & $30 \mathrm{~cm}$ & $\begin{array}{l}\text { Fine-medium, bluish sand } \\
\text { layers (upto } 5 \mathrm{~mm} \text { thick) } \\
\text { within lake mud, } \\
\text { rich in organic debris, } \\
\text { charcoal abundant }\end{array}$ & $\begin{array}{l}\text { Ilyocypris gibba (RAMDOHR) } \\
\text { I. bradyi, SARS } \\
\text { Eucypris afghanistanensis, } \\
\text { HARTMANN } \\
\text { Candona candita, } \\
\text { (O. F. Mueller) }\end{array}$ & Succineasp. & $\begin{array}{l}\text { Chara } \\
\text { globularis, } \\
\text { ThunLLIER (G) }\end{array}$ \\
\hline MV2 & $1.5 \mathrm{~m}$ & $\begin{array}{l}\text { Medium grained sand } \\
\text { within carbonaceous } \\
\text { mud, rich in organic } \\
\text { debris }\end{array}$ & $\begin{array}{l}\text { I. bradyi } \\
\text { E. afghanistanensis }\end{array}$ & $\begin{array}{l}\text { Lymnaea sp. } \\
\text { Succinea sp. } \\
\text { Gyraulus sp. }\end{array}$ & C. globularis (o) \\
\hline MV3 & $6.4 \mathrm{~m}$ & $\begin{array}{l}\text { Greyish medium sand } \\
\text { embedded within bluish } \\
\text { clay, plant remains and } \\
\text { charcoal }\end{array}$ & E. afghanistanensis & $\begin{array}{l}\text { Lymnaea sp. } \\
\text { Succineasp. }\end{array}$ & C.globularis (G) \\
\hline MV4 & $17.0 \mathrm{~m}$ & $\begin{array}{l}\text { Fine coarse sand lenses } \\
\text { within bluish silty clay, } \\
\text { interlayered with } \\
\text { carbonate strata, abundant } \\
\text { plant remains, } \\
\text { charcoal }\end{array}$ & E. afghanistanensis & Succineasp. & $\begin{array}{l}\text { C. globularis } \\
\text { (MG) }\end{array}$ \\
\hline MV5 & $24.8 \mathrm{~m}$ & $\begin{array}{l}\text { Yellow, } \mathrm{cm} \text { thick silty clay } \\
\text { interbedded with sand } \\
\text { and carbonate layers, } \\
\text { abundant plant remains }\end{array}$ & E. afghanistanensis & $\begin{array}{l}\text { Lymnaea sp. } \\
\text { Succinea sp. }\end{array}$ & $\begin{array}{l}\text { C.globularis } \\
(\mathrm{MG}, \mathrm{O})\end{array}$ \\
\hline MV6 & $27.8 \mathrm{~m}$ & $\begin{array}{l}\text { Silty clay interbedded } \\
\text { with sand layers, } \\
\text { abundant plant remains }\end{array}$ & 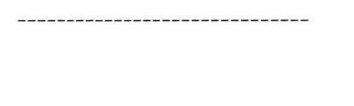 & Succineasp. & --------------------- \\
\hline MV7 & $31.7 \mathrm{~m}$ & $\begin{array}{l}\text { Yellowish silty clay } \\
\text { lenses within medium sand } \\
\text { and carbonate } \\
\text { layers, rich } \\
\text { plant remains }\end{array}$ & E. afghanistanensis & Succineasp. & - \\
\hline MV8 & $37.0 \mathrm{~m}$ & $\begin{array}{l}70 \mathrm{~cm} \text { thick carbonate } \\
\text { layer }\end{array}$ & E. afghanistanensis & $\begin{array}{l}\text { Lymnaea sp. } \\
\text { Succinea sp. }\end{array}$ & C.globularis $(\mathrm{O})$ \\
\hline MV9 & $56.0 \mathrm{~m}$ & $\begin{array}{l}\text { Medium sand interlayered } \\
\text { with slity clay/carbonate }\end{array}$ & E. afghanistanensis & - & \\
\hline
\end{tabular}

BP. Although the recovered fossils are no precise indicator of age, the ostracods found in the sequence have generally been reported from Pleistocene-Holocene sediments in various parts of the world (Bhatia, 1968; Siddiqui, 1971; Delorme, 1971; Singh, 1974; Diebel \& Pietrzeniuk, 1975; LÖFFler, 1977; Robinson, 1978; De DeckKer, 1979; KrSTIC, 1988; Frausum \& WOUTERS, 1990).

\section{Description of Faunal and Floral Finds}

In the lithocolumn, nine fossiliferous horizons (Fig. 1c), yielding ostracods, gastropods, and charophytes with their gyrogonites and/or oospores were located (Table 1). MV1-MV3, rich in organic debris, were located within the lacustral unit, sediments of which were deposited below wave 
Table 2: Comparison of biometric data between Chara globularis (subfossil) and Chara elongata (fossil). Mean values in parentheses.

Tab. 2: Vergleich der biometrischen Daten von Cbaraglobularis (subfossil) und Chara elongata (fossil). Mittelwerte in Klammern.

\begin{tabular}{|l|c|c|}
\cline { 2 - 3 } \multicolumn{1}{c|}{} & $\begin{array}{c}\text { Chara globularis } \\
\text { 100 gyrogonites } \\
\text { (sample MV4) }\end{array}$ & $\begin{array}{c}\text { Chara elongata } \\
\text { ca. 100 gyrogonites } \\
\text { (from SchWARZ 1985) }\end{array}$ \\
\hline $\begin{array}{l}\text { length of } \\
\text { polar axis } \\
{[\mu \mathrm{m}]}\end{array}$ & $740-970(825-900)$ & $660-1010(750-850)$ \\
\hline $\begin{array}{l}\text { largest } \\
\text { equatorial } \\
\text { diameter }[\mu \mathrm{m}]\end{array}$ & $520-660(550-625)$ & $420-740(450-525)$ \\
\hline $\begin{array}{l}\text { iso- } \\
\text { polarity } \\
\text { index }\end{array}$ & $122-170(135-145)$ & $125-200(150-170)$ \\
\hline $\begin{array}{l}\text { equatorial } \\
\text { cell diameter } \\
{[\mu \mathrm{m}]}\end{array}$ & $60-100(80)$ & $60-110(80-90)$ \\
\hline $\begin{array}{l}\text { number } \\
\text { of } \\
\text { convolutions }\end{array}$ & $9-13(11)$ & $9-13(10-11)$ \\
\hline $\begin{array}{l}\text { diameter of } \\
\text { basal pore } \\
\text { [ } \mu \mathrm{m}]\end{array}$ & $30-70(50-60)$ & $30-100(40-60)$ \\
\hline
\end{tabular}

base conditions. MV4-MV8 were located within a unit, the deposition of which took place while the delta building activity in the lake was in process (Kotlia et al., 1997b). In addition to the above mentioned characteristics, these horizons also contain oncoliths as well as numerous plant remains (e.g., leaf imprints, stems, twigs, seeds) preserved along the bedding planes. MV4-MV8 have also yielded unidentifiable bone fragments of microvertebrates. MV9 was located within the fluvial deposit of channel sands in which comparatively less carbonate deposition is found.

Among the gastropods, Lymnaeasp. (Plate 1, figs. $a-b)$ is large-sized with a sharp elongate spire and a characteristic aperture. Morphologically, it is very similar to Lymnaea (Galba) andersoniana which is common in the Pleistocene lacustrine deposits of Kashmir, NW Himalaya (BНATIA, 1974). Succinea sp. (Plate 1, fig. c) has one whorl with oval shaped aperture. It is essentially the Himalayan form and is known from Kashmir, Panjab and Kumaun Himalayas (PRASAD, 1937). Gyraulus sp. (Planorbidae) comprises of gradually opening whorls (Plate 1, fig. d) with concave dorsal side and flat ventral side. It has been recorded in the fossil forms from the Plio-Pleistocene of the Siwaliks and lake deposits of Panjab and Kashmir respectively (Bhatia \& Mathur, 1973). Even today, Gyraulus lives in the modern lakes of Ladakh at an altitude of 3,000-3,500 $\mathrm{m}$ in cold climate with temperatures between 5 and $8^{\circ} \mathrm{C}$.

Among ostracods, abundance of llyocypris (l. gibba RAMDOHR and $l$. bradyi, SARS) in MV1-MV2 and widespread occurrence of Eucypris afghanistanensis, HARTMANN throughout the sequence is recorded. The difficulties in identification of the representatives of llyocypris have been commented upon by a number of workers (SIDDIQUI, 1971; Singh, 1974; VAn Harten, 1979; Preece et al., 1986; Robinson, 1990). On one hand, the noded and smooth forms are considered as two extremes of a single genus, while on the other hand, two such forms are regarded as two distinct species. Following Holmes (1996), we have, in this study, assigned tuberculate forms to I. gibba (Plate 1, figs. e-h) and non-tuberculate forms to $I$. bradyi (Plate 1, figs. i-j). Although I. gibba has some degree of variation in tubercle strength, the major dorsal scars are more or less fused and the mandibular scars are roundish. In external view its ventrum is slightly concave and the dorsum is oblique tapering posteriorly.

In $I$. bradyi, the dorsum is somewhat straight and the ventrum is concave. It lacks strong tubercles and the major dorsal scars are not fused.

Eucypris afghanistanensis HARTMANN is the first report from the Pleistocene of northwest India. The shell is arched on the dorsal side. The greatest height is slightly before the middle from where the anterior side forms a shallower slope compared to that towards the posterior side (Plate 1, figs. k-p). The anterior border is flat and has its maximum convexity in the lower third of the valve. The posterior end is narrow and more acute than the anterior end. The ventral margin is distinctly concave in the median part. Candona candita (O. F. MuELLER) has an elongate carapace outline (Plate 1, fig. t). The dorsum is strongly curved while the ventrum is centrally concave. The anterior margin is narrowly rounded while the posterior margin is somewhat truncated.

The charophytes, represented by both oospores and gyrogonites (Plate 2, figs. a-p), are assignable to the Recent Chara globularis THUILLIER 1799 (= Chara fragilis Desvaux 1810), a species of the section Grovesia of the genus Chara (cf. WOOD \& IMAHORI 1965). The gyrogonites, sometimes very abundant (e.g., in MV4-MV5), can be described as 
follows: The general shape of the gyrogonites is elliptic to oval. The apical pole, as a rule, is well rounded, not standing out against the general outline, in rare cases a little protruding. The basal pole is generally slightly tapering, subtruncate at the very tip and rarely well rounded. The spiral cells are smooth, without ornamentation, predominantly flat, occasionally faintly concave or convex, and the intercellular ridges are very fine, somewhat more conspicuous only in the apical area. In the apical periphery, the spiral cells are slightly decreased in width without reduction in thickness. They are distinctly concave without exception, even in gyrogonites with otherwise flat spiral cells. A marked enlargement of spiral cells is observed in the apical centre, those partly resting concave, partly conspicuously thickened at their ends and forming an indistinct "apical rosette", more so in gyrogonites with strongly calcified spirals. The basal pore is pentagonal, superficial, sometimes with a shallow crateriform depression. The basal plug is pentagonal, plate shaped, ca. $45 \mu \mathrm{m}$ in height with the upper surface ca. $120 \mu \mathrm{m}$ in width. The biometric data (Table 2) and the morphology of these sub-fossil gyrogonites perfectly match with the description and illustrations of Recent gyrogonites of Chara globularis, reported by earlier workers (e.g., Horn af Rantzien, 1959; Krause, 1986, Soulie-MÄrsche, 1989). The present gyrogonites show very close morphological resemblance with Chara elongata from the Upper Oligocene/Lower Miocene of Central Europe (cf. SCHWARz, 1985). However, Chara elongata has more elongated gyrogonites; it thus has a greater isopolarity index (see Table 2).

\section{Palaeoecological Remarks}

Ostracods are common constituents of the carbonate sediments and their occurrence along with charophytes in this sequence add palaeoecological significance. Such an ideal combination of ostracods-charophytes, for the first time, was reported from a fresthwater Late-glacial lake in Strathmore (Lyell, 1824). A number of factors, e.g., size, turbidity, permanence of water body and its temperature, nature of lithological units etc. may control the occurrence of ostracods. Ilyocypris is abundant in MV1, present in MV2 and absent thereafter. I. bradyi, a typical cold water species (Frausum \& Wouters, 1990) is stenothermal (DE DeCKker, 1979) and holarctic (Diebel \& PietrzenIUK, 1977). It is reported in abundance from open water deposits of shallow palaeolakes (HoLmes et al., 1992), generally associated with a rich vegeta- tion (Bhatia, 1968; Singh, 1974) and is found predominantly burrowing or crawling among aquatic plants and organic debris (PreEce et al., 1986). It prefers water of low salinity (DiEBEL \& PIETRzENIUK, 1975) and is abundant in the sediments of a Himalayan palaeolake which had permanent outflow during its existence (Holmes et al., 1992).

However, I. gibba is an active swimmer (VAN HARTEN, 1979; PREECE et al.; 1986) and I. bradyi notably can not swim (VAN HARTEN, 1979), so that the abundance of both in MV1 appears to be of palaeoecological significance. I. gibba is common in slow flowing waters with temperatures between 4 and $19.5^{\circ} \mathrm{C}$ (Alm, 1916 cited in Diebel \& Pietreniuk, 1975; DE DeCKKer, 1979). We think that during the lacustrine deposition, I. gibba may have lived in the water column, whereas I. bradyi preferred the lake margins. A number of shells of Pisidium (a bivalve which according to BHATIA (1974) is indicative of lacustrine conditions) in the MV1-MV2 horizons provides additional support, in addition to the nature of the sedimentation pattern, for a lacustrine environment during the deposition of the basal beds in the sequence.

Eucypris afghanistanensis, present almost throughout the sequence, is cold stenothermal and lives in cold water springs and streams (HARTMANN, 1964). It is a poor swimmer. All species of Eucypris (except E. lutaria) are cold water forms and hence are significant climatic indicators (HARTMANN, 1964). Today, E. afghanistanensis or similar forms live in the Himalayas at an altitude of up to $4,500 \mathrm{~m}$ (HaRTMANN, 1975). E. pigra, a cold and stenothermal species (DiEbel \& PIETRZENIUK, 1977) lives in the higher altitudes of the Alps at temperatures below $12^{\circ} \mathrm{C}$ (LüTTIG, 1959), and is found together with $E$. virens at altitutes of $2,000 \mathrm{~m}$ or more (HARTMANN, 1975). E. zenkeri, another similar species, is a characteristic form of slowly flowing, cold, shallow, and plant-rich waters (SIDDIQUI, 1971). Today, a number of species of Eucypris from China are found in cold climate with annual mean temperatures between -5 and $-8^{\circ} \mathrm{C}$ with a salinity below $5 \%$ (YANG, 1988) although it is also present up to $+2{ }^{\circ} \mathrm{C}$ in certain areas. On the basis of the widespread presence of E. afghanistanensis almost throughout the existence of the Lamayuru lake, we suggest that the palaeolake was shallow with abundant plant material around, and the slow flowing water was cold, probably colder than today and in which cold loving ostracods, e.g., Eucypris and Ilyocypris flourished. Candona candita also registers its presence in the Lamayuru sequence. A cold water form of freshwater environ- 
ments, it is stenothermal (KLIE, 1938). Most species of Candona are usually found burrowing amongst organic debris on the beds of lakes and ponds (HOlmes, 1996). It has holarctic distribution (DieBeL \& PieTRZENIUK, 1975, 1977).

Earlier mention of Parastenocypris, HARTMANN from these deposits (ForT et al., 1989; KOTlia et al., 1997b) also supports our palaeoecological interpretation. Parastenocypris is characteristic of shallower channels of cold waters (SINGH, 1974), and is frequently found in the freshwaters of India (HARTMANN, 1975)

Today, Chara globularis has nearly cosmopolitan distribution (CORILlion, 1957; HORN AF RANTZIEN, 1959) but is centered around the northern hemisphere. It ranges from arctic regions (Greenland, Iceland) to tropical latitudes. In India, it is part of the Recent flora (VAIDYA, 1967), and has been reported to occur in several Holocene palaeolakes in north India, dated from 8,500 to $2,800 \mathrm{yr}$. BP (BHATIA \& SinGH, 1989). As can be expected from its present geographic distribution, Chara globularis tolerates a wide range of ecological factors. However, slow flowing, calm, slightly carbonaceous waters without heavy currents offer optimum growing conditions. But, unlike most other species of Chara, it adapts to fairly low calcium levels (HORn AF RANTZIEN, 1959) and even ventures into slightly acidic waters. It is often found growing intermingled with phanerogamic plants in rather eutrophic environments (KRAUSE, 1997), a feature seldom encountered with charophytes, which tend to form pure submerse "chara stands". The maximum water depth suited for colonisation is controlled by transparency of the water body; thus, shallow water (normally below $5-10 \mathrm{~m}$ ) is favoured. Although freshwater not is preferred, LUTHER (1951) mentioned finds from even mesohaline conditions in the Baltic Sea. Chara globularis has been reported from shallow waters beneath the ice cover as well as from hot springs.

Abundance of oncoliths (as in MV4-MV8) indicates shallow water conditions. The deposition of organically rich carbonate which probably favoured the growth of oncoliths may typify the semiarid to arid alpine environment (FORT et al., 1989) in delta platforms (as MV4-MV8 horizons in our section), in areas which only occasionally receive the clastic influx (OviaTt et al., 1994). The assumed shallow water conditions for the depositon of MV4-MV8 may further be strengthened by the presence of abundant plant material on the bedding planes as such a situation would demand shallow enough shoreline conditions for plants to flourish during the times of submersion and emersion (ForT et al., 1989).

\section{Discussion and Conclusion}

The Lamayuru lake was formed sometime between 35,000-40,000 yr BP either due to heavy landslides (FORT et al. 1989) or due to tectonically induced damming of the Lamayuru drainage. An event of formation of various tectonic lakes in the Central Himalaya (e.g., Bhimtal, 40,000 yr BP, KoTLiA et al., 1997a), Kumaun Himalaya (Wadda lake, 37,000 yr BP, Kotula et al., communicated), Tethys Himalaya (Late Pleistocene, Mohindra \& BAGATI, 1996), eastern Ladakh (e.g., Tsokar ca. 35,000 yr BP, Bhattacharyya, 1989) and western Ladakh (e.g., Lamayuru) provides evidence for a prominent tectonic activity throughout the Indian Himalayas between 35,000 and 40,000 yr BP. Evolution of a series of tectonic lake basins around this time in China (FANG, 1991) and western China (RHOdes et al., 1996) probably adds to the significance of this tectonic event in Asia.

In the palaeolake, the sedimentation took place in form of lacustrine muds, deltas, fluvial sands and colluvial debris flow. During the lacustrine sedimentation, the swimming ostracods may have lived in running/moving waters, whereas, the nonswimmers may have occupied the lake margins burrowing on aquatic plants and organic debris. During the delta building, highly dissolved carbonate favoured the growth of charophytes and ostracods. Under semiarid to arid conditions, the lake may have had low salinity because of continuous outflow. This is evidenced by the widespread occurrence of Eucypris which according to Holmes (1992) prefers very low salinity waters. The shallow water conditions are evidenced by the presence of numerous oncoliths, the majority of weak or non-swimmer ostracod species, the abundance of Chara globularis in most of the fossil horizons and the occurrence of shallow shoreline produced plant remains. The temperature of the lake may have been low as most ostracods found in our sequence are characteristic of cold waters.

A number of Ladakhi palaeolake profiles in the Main Himalayan crest, as mentioned in the text, bear a striking similarity with Lamayuru deposits in sedimentation pattern including carbonate-rich layers. However, if compared with the deposits of closed inland basins of the Himalaya, there appears to be a contrast. While the closed inland basins are characterised by carbonaceous muds and extensive peat deposits with low frequency of fossil ostracods, the Lamayuru deposits are domi- 
nated by oxidized and biologically rich carbonates which are very rich in ostracods. An example for such a situation is the Karewa lake basin of Kashmir on the southwestern side of the Himalaya. The Lower Karewa lake profile is composed of mainly blue/black massive muds and has a poor ostracod fauna. On the other hand, the Upper Karewa lake sediments, interpreted as open-water deposits of a shallow lake with associated lake margins and fluvio-deltaic facies (Holmes et al., 1992), consist of variable proportions of oxidized carbonate of biogenic and detrital origin, and have yielded an extremely rich ostracod fauna.

Approximately around 1000 yr BP (ForT et al., 1989), a sudden pulse of tectonic uplift may have caused the instability in the area which resulted in a considerable mass of debris flow from adjacent mountain slopes that was poured into the valley and breached the lake. Our observations suggest that the structural disruption of the lake floor prior to the onset of debris flow may have been tectonically induced. Nevertheless, because of the obliterated top of the debris flow deposit, a precise date for the depletion of lake is not available at the moment and is under study. Characterised by polymodal palaeocurrent patterns (KoTLIA et al., 1997b), this poorly sorted deposit was supplied from nearby sources, e.g., surrounding mountains, without long distance transportation. We think that this tectonic event may be synchronous with the formation of the younger of the two prominent terraces along the Indus river. This river terrace, $10-40 \mathrm{~m}$ in thickness, is composed of ill-sorted colluvial gravel with brownish clay and sand horizons and an enormous sandy/muddy matrix and is exposed extensively along the Indus and Lamayuru rivers. This terrace, symmetrically arranged on both sides of the Indus and Lamayuru rivers, is composed of fluvial gravels in addition to angular and sub-angular rock fragments and does not show any characteristic feature (e. g. striations, polishing etc.) of glacial deposits. The termination of a number of Himalayan palaeolakes as a result of tectonic instability has been demonstrated by a number of workers in India (VALDIYA et al., 1992, 1996; Kotlia, 1995; Kotlia et al., 1997a) as well as in the Pakistan Himalayas (BurBank, 1983).

\section{Acknowledgements}

Financial assistance for field trips was provided by the University Grants Commission and Department of Science and Technology, New Delhi. The laboratory work was supported by the Alexander von Humboldt Stiftung, Germany through a generous grant in form of AvH fellowship to BSK. We are most grateful to Dr. Erika Pietrzeniuk, Berlin for improving our identification of ostracods as well as for providing the required literature, to Prof. Dr. W. v. Koenigswald, Bonn for encouragement, and to Dr. G. Rajagopalan, Lucknow for providing a radiocarbon date. Help given by Mr. B. S. Dhalla in several ways is thankfully acknowledged.

\section{References}

Agrawal, D.P. Dodia, R., Kotlia, B.S., Razdan, H. \& SaHNI, A. (1989): The Plio-Pleistocene geologic and climatic record of the Kashmir valley: A review and new data. Palaeogeogr. Palaeoclimatol. Palaeoecol., 73: 267-286; Amsterdam.

Bagati, T.N., Mazari, R.K. \& Rajagopalan, G. (1996): Palaeotectonic implication of Lamayuru lake (Ladakh). Curr. Sci., 71(6): 479-482; Bangalore.

Bhatia, S.B. (1968): Pleistocene ostracods from the Upper Karewas of Kashmir. Micropal., 14(4): 465-483; New York.

- (1974): Some Pleistocene molluscs from Kashmir, India. Him. Geol., 4: 371-395; Dehradun.

- \& Mathur, A.K. (1973): Some Upper Siwalik and Late Pleistocene molluscs from Punjab. Him. Geol. 3: 24-58; Dehradun.

- \& SingH, N. (1989): Holocene charophytic flora of parts of Uttar Pradesh, India; Biogeographical implications. First Intern. Symp. on Charophytes, 4-8 July, 1989, Montpellier, Abstracts, p. 5; France.

BhatTacharyya, A. (1989): Vegetation and climate during the last 30,000 years in Ladakh. Palaeogeogr. Palaeoclimatol. Palaeoecol., 73: 25-38; Amsterdam

Burbank, D. W. (1983): Multiple episodes of catastrophic flooding in the Peshawar basin during the past 700,000 years. Geol. Bull. Univ. Peshawar, 16: 43-49; Pakistan.

- \& BEck, R. A. (1989): Early Pliocene uplift of the Salt Range; Temporal constraints on thrust wedge development, northwest Himalaya, Pakistan. Geol. Soc. Amer. Spl. Papers, 232: 113-128; Boulder.

- \& Johnson, G. D. (1982): Intermontane-basin development in the past $4 \mathrm{Myr}$ in the north-west Himalaya. Nature, 298 (5873): 432-436; London.

Bürgisser, H. M. Gansser, A. \& PiKA; J. (1982): Late glacial lake sediments of the Indus valley area, northwestern Himalaya. Eclogae Geologica Helvet., 75 (1): 51-63; Basel.

Butler, R.W. H., Coward, N.P., Harwood, G.M. \& KNIPE, R.J. (1987): Salt, its control on thrust geometry, structural style and gravitational collapse along the Himalayan mountain front in the Salt Range of Pakistan. In: O'Brien, J. J. \& Lesche, L. (eds.)-Dynamical Geology of Salt and Related Structures, Austin, Academic Press: 399-418.; Texas.

Corillion, R. (1957): Sur la répartition géographique des Charophycees vivantes. C.R. Seanc. Soc. Biogeogr., 299-301; 122-156; Paris. 
Cronin, V.S. (1982): The physical and magnetic polarity stratigraphy of the Skardu basin, Baltistan, Northern Pakistan. Master's Thesis, Dartouth College; Hanover.

- (1989): Structural setting of the Skardu intermontane basin, Karakoram Himalaya, Pakistan. Geol. Soc. Amer. Spl. Papers, 232: 183-201; Boulder.

De Deckker, P. (1979): Middle Pleistocene ostracod fauna of the west Runton freshwater bed, Norfolk. Palaeontology, 22: 293-316; London.

Delorme, L.D. (1971): Palaeoecological determinations using Pleistocene freshwater ostracods. In: OERTLI, H.J. (ed.)-Palaeoecologie Ostracodes (1970), Bull. Centre de Res. Pau-SNPA, 5: 341-347, Pau.

Diebel, V.K. \& Pietrzeniuk, E. (1975): Ostracoden aus dem holozänen Travertin von Bad Langensalza. Quartarpaläontologie, 1: 27-55; Berlin.

- (1977): Ostracoden aus dem Travertin von Taubach bei Weimar. Quartarpaläontologie, 2: 119-137; Berlin.

FANG, J.Q. (1991): Lake evolution during the past 30,000 years in China and its application for environmental change. Quat. Res., 36: 37-60; Washington.

FORT, M. (1980): Les formations quaternaires lacustres de la basse Thakkhola Himalaya du Nepal: intérêt paléogéographique, néotectonique et chronologique. Comptes Rendus de I'Académié des Sciences de Paris, Hindustan Publ. Corporation 2: 39-58; New Delhi.

- Burbank, D.W. \& Freytet, P. (1989): Lacustrine sedimentation in a semiarid alpine setting: An example from Ladakh, northwestern Himalaya. Quat. Res., 31: 332-350; Washington.

Frank, W., Gansser, A \& TrommsdorfF, V. (1977): Geological observations in the Ladakh area (Himalayas).-A preliminary report. Schweiz. Min. Pet. Mitt., 57: 89113; Switzerland.

Frausum, A.V. \& Wouters, K. (1990): Ostracoda from Holocene calcareous tufa deposits in southern Belgium: a palaeoenvironmental analysis. In: Ostracoda and Global Events (eds.)- Whatley, R. \& Maybury, C., Chapman and Hall: 505-511; London.

Gansser, A. (1964): Geology of the Himalayas. Interscience Publishers, p. 289; London.

- (1977): The great suture zone between Himalaya and Tibet. A preliminary account. Himalaya-Sciences de la terre Colloqes Internationaux. Ed. du Centre National de la Recherche Scientifique, 268: 181-192.; Paris.

GEE, E.R. (1989): Overview of geology and structure of the Salt Range, with observations on related areas of north Pakistan. Geol. Soc. Amer. Spl. Papers, 232 95-112.; Washington.

Hartmann, G. (1964): Asiatische Ostracoden, systematische und zoogeograhphische Untersuchungen. Intern. Revue Hydrobiol., 3: 54-59; Berlin.

- (1975): Klassen und Ordnungen des Tierreichs: Ostracoda, VEB Gustav Fischer Verlag, Jena, 2 (4): 569-786; Berlin.

Holmes, J. A. (1992): Nonmarine ostracods as Quaternary palaeoenvironmental indicators. Progress Physical Geogr., 16 (4): 405-431; London.
- (1996): Ostracod faunal and microchemical evidence for Middle Pleistocene sea level change at Clacton-on-Sea (Essex, U.K.). In: KeEN, M.C. (eds.)- Proc. 2nd Europe. Ostracod. Meet., British Micropalaeontal. Soc. Publ: 135-140; London.

- Hales, P. E. \& Street-Perrott, F. A. (1992): Trace element chemistry of non-marine ostracods as a means of palaeolimnological reconstruction: An example from the Quaternary of Kashmir, northern India. Chem. Geol., 95: 177-186; Amsterdam.

Horn aF RANTZIEN, H. (1959): Recent charophyte fructications and their relations to fossil charophyte gyrogonites. K. Svenska Vet. Akad. Arkiv. Bot. ser., 2, 4 (7): 165-332; Lund.

KuIE, W. (1938): Ostracoda. Tierwelt Deutschlands, 34: 1230 , Jena.

Kotlia, B. S. (1995): Upper Pleistocene Soricidae and Muridae from Bhimtal-Bilaspur deposits, Kumaun Himalaya, India. Jour. Geol. Soc. India, 46(2): 177190; Bangalore.

- Bhalla, M. S., Sharma, C., Rajagopalan, G., Ramesh, R., Chauhan, M. S., Mathur, P. D., Bhandari, S. \& Chacko, S. T. (1997A): Palaeoclimatic conditions in the Upper Pleistocene and Holocene Bhimtal-Naukuchiatal lake basin in south-central Kumaun, north India. Palaeogeogr. Palaeoclimatol. Palaeoecol., 130: 307-322; Amsterdam

- Shukla, U. K., Bhalla, M. S., Mathur, P. D. and Pant, C.C. (1997b): Quaternary fluvio-lacustrine deposits of the Lamayuru basin, Ladakh Himalaya: Preliminary multidisciplinary investigations. Geol. Mag., 134 (6): 807-815; Cambridge.

- Bhalla, M. S., Shah, N. \& Rajagopalan, G. (1998): Palaeomagnetic results from the Pleistocene-Holocene lake deposits of Bhimtal and Bhowali (Kumaun) and Lamayuru (Ladakh) Himalaya with reference to the reversal events. Jour Geol. Soc. India, 51 (1): 7-20; Bangalore.

- Sharma, C., Bhalla, M.S., Rajagopalan, G., Subrahmanyam, K., Bhattacharyya, A. \& Valdiya, K.S. Palaeoclimatic conditions in the Late Pleistocene Wadda lake (Pithoragarh), Kumaun Lesser Himalaya. Palaeogeogr. Palaeoclimatol. Palaeoecol. (communicated); Amserdam.

Krause, W. (1986): Zur Bestimmungsmöglichkeit subfossiler Characeen-Oosporen an Beispielen aus Schweizer Seen. Vjschr. Naturforsch. Ges. Zürich, 131(4): 295-313; Zürich.

- (1997): Charales (Charophyceae). In: ETTL, H., GÄrTner, G., Heynig, H. \& Mollenhauer, D. (Eds.)-Süßwasserflora von Mitteleuropa, 18, 202p.; Jena, Stuttgart, Lübeck, Ulm (Gustav Fischer).

Krstic, N. (1988): Some Quaternary ostacods of the Pannonian basin with a review of few neglectoida. In: Henai, T., Ikeya, N. \& Ishizaki, K. (eds.)- Evolutionary Biology of Ostracoda: Its Fundamentals and Applications, 1063-1085; Amsterdam.

LÖFfler, H. (1977). Fossil meromixis in Kleinsee (Carinthia) indicated by ostracods. In: LÖFFLER, H. \& DANIELOPOL, D. (eds.)- Aspects of Ecology and Zoogeography of Recent and Fossil Ostracods. Junk b.v. Publishers: 321-326; The Hague. 
LuTHER, H. (1951): Verbreitung und Ökologie der höheren Wasserpflanzen im Brackwasser der Ekenäaegend in Südfinnland. Acta Botanica Fennica, 49: 1-23 and 50: $1-370 ;$; Helsingfors.

LÜTTIG, G. (1959): Die Ostracoden des Spätglazials von Tatzmannsdorf (Burgenland). Paläontol. Z., 33: 185197; Stuttgart.

LyELL, C. (1824): On a recent formation of freshwater limestone in Forfarshire and on some recent deposits of freshwater marl with a comparison of recent with ancient freshwater formations, and an appendix on the Gyrogonite or seed-vessel of the Chara. Trans. Geol. Society, London, ser. 2(2): 73-96; London.

Mohindra, R. \& Bagati, T.N. (1996): Seismically induced soft-sediment deformation structures (seismites) around Sumdo in the lower Spiti valley (Tethys Himalaya). Sed. Geol., 101: 69-83;

NaKATA, T. (1975): On Quaternary tectonics around the Himalayas. Sci. Report Tohoku Univ., ser. 7, 25 (1): 111-118; Hiroshima.

Opdyke, N.D., Shackleton, N. J. \& HaYs, J.D. (1974): The details of a magnetic excursion as seen in a piston cOre from the southern Indian Ocean. Trans. Amer. Geophys. Union, 55: 237-242.

Oviatt, C. G., Sack, D. \& Currey, D. R. (1994): The Bonneville basin, western United States. In: GIERLowskIKordesch, E. \& Kelts, K. (eds.)- Global Geological Records of Lake Basins, Cambridge Univ. Press, 1: 371-375; Cambridge.

Owen, L.A. (1988): Terraces, uplift and climate in Karakorum mountains, northern Pakistan. Unpublished P.h.D. Thesis, University of Leicester.

Prasad, B. (1937): Scientific results of Yale North India Expedition, biological Report. Rec. Ind. Mus., 39(3): 261-280; Calcutta

Preece, R.C., Thorpe, P.M. \& Robinson, J.E. (1986): Confirmation of an interglacial age for the Condat Tufa (Dordogne, France) from biostratigraphic and isotopic data. Jour. Quat. Sci., 1: 57-65; Oxford.

Rhodes, T.E., Gasse, F., Rutfen, L., Fontes, J.C., KeqIn, W., Bertrand, P., Gilbert, E., Melieres, F., Tucholka, P., Zhixiang, W. \& Zhi-Yuan, C. (1996): A Late Pleistocene-Holocene lacustrine record from lake Manas, Zunggar (northern Xinjiang, western China). Palaeogeogr. Palaeoclimatol. Palaeoecol., 120: 105-121; Amsterdam.

Robinson, E. (1978): The Pleistocene. In: Bate, R. H. \& RoBINSON, E. (eds.)- A Stratigraphic Index of British Ostracoda. Geol. Jour. Spl. Issue No. 8, Seel House Press, 6: 457-472; Liverpool.

Robinson, J.E. (1990): The ostracod fauna of the Middle Pleistocene interglacial deposits at Little Oakley, Essex. Phil. Trans. Royal Soc., B 328: 409-423; London.

Sangode, S.J. \& Bagati, T.N. (1995): Tectono-climatic signatures in higher Himalayan lakes: A palaeomagnetic/rock magnetic approach in the lacustrine sediments of Lamayuru, Ladakh, India. Jour. Him. Geol., 6 (1): 51-60; Dehradun.

Schwarz, J. (1985): Revision der Charophyten-Flora der Süßwasserschichten und des Kalkteriärs im Mainzer Becken (Ober-Oligozän-Unter Miozän). Mainzer Geowiss. Mitt., 14: 7-98; Mainz.

Shroder, J. F., Khan, S. M., Lawrence, R. D. \& Madin, I. P.
(1986): Chronology and deformation of Quaternary sediments, middle and upper Indus, Pakistan. Geol. Soc. Amer. (Abstracts with Programs), 18: 749; Boulder.

- Higgins, S.M. (1989): Quaternary glacial chronology and neotectonics in the Himalaya of northern Pakistan. Geol. Soc. Amer. Spl. Papers, 232: 275-294; Boulder.

SidDiqui, Q. A. (1971): The palaeoecology of non-marine Pleistocene ostracoda from Fladbury, Worcestershire and Isleworth, Middlesex. In: Oertu, H. J. (ed.)Palaeoecologie Ostracodes (1970), Bull. Centre de Res. Pau-SNPA, 5: 331-339, Pau.

SINGH, D., (1974): Some new freshwater ostacods from Kashmir, India. Bull. Ind. Geol. Assoc., 6: 157-176; Chandigarh.

Soulie-Märsche, I. (1989): Étude comparée de gyrogonites de Charophytes actuelles et fossiles et phylogénie des genres actuels. Edition révisée de la Thèse d'Etat, Univ. Montpellier, 1979:257 pp; Milau, France.

SRIKANTIA, S.V. \& RAZDAN, M.L. (1980): Geology of part of central Ladakh Himalaya with particular reference to Indus Suture Zone. Jour. Geol. Soc. India, 21: 523545; Bangalore.

THAKUR, V.C. (1981): Regional framework geodynamic evolution of the Indus Tsangpo Suture Zone in the Ladakh Himalaya. Earth Sci., 72: 89-97; Calcutta.

VAIDYA, B.S. (1967): Study of some environmental factors affecting the occurrence of charophytes in western India. Hydrobiologia, 29: 256-262; The Hauge.

Valdiya, K. S., Kotlia, B. S., Pant, P. D., Shah, M., Mungali, N., Tewari, S., Shah, N. \& Upreti, M. (1996): Quaternary palaeolakes in Kumaun Lesser Himalaya: Finds of neotectonic and palaeoclimatic significance. Curr. Sci., 70 (2): 157-160; Bangalore

- Rana, R. S., Sharma, P. K. \& Dey, P. (1992): Active Frontal Fault, Main Boundary Thrust and Ramgarh Thrust in southern Kumaun. Jour. Geol. Soc. India. 40(6): 509-528; Bangalore.

VAN HARTEN, D. (1979): Some new shell characters to diagnose the species of llyocypris gibba-biplicata-bra$d y i$ group and their ecological significance. In: KRSTIC, N. (ed.)- Taxonomy, Biostratigraphy and Distribution of Ostracodes, Serbian Geol. Soc., 71-76; Beograd.

WOOD, R.D. \& IMAHORI, K. (1965): A revision of the Characeae. 2 vol., 904 p., 394 pl.; Weinheim (J. Cramer).

YANG, F. (1988): Distribution of the brackish-salt water ostracods in northwestern Qinghai Plateau and its geological significance. In: HenaI, T., Ikeya, N. \& IsHIZAKI, K. (eds.)- Evolutionary Biology of Ostracodes, Elsevier: 519-530; Amsterdam.

Manuskript eingegangen am 19. März 1998 


\section{Explanations of Plate 1 and 2 (Appendix):}

PLATE I:

a) Lymnaeasp., x35 (sp. no. 1225, horizon MV5)

b) Lymnaea sp., x37 (sp. no. 1248, horizon MV8)

c) Succineasp., x50 (sp. no. 1250, horizon MV8)

d) Gyraulussp., x50 (sp. no. 1200, horizon MV2)

e) llyocypris gibba (RAmDoHR), x55, LV ext. (sp. no. 1173, horizon MV1)

f) I. gibba, x69, LV, int. (sp. no. 1172, horizon MV1)

g) I. gibba, x71, RV, ext. (sp. no. 1170, horizon MV1)

h) I. gibba, x69, RV, int. (sp. no. 1175, horizon MV1)

i) I. bradyi, SARS, x61, LV, ext. (sp. no. 1178 , horizon MV1)

j) I. bradyi, x63, RV, ext. (sp. no. 1177, horizon MV1)

k) Eucypris afghanistanensis, Hartmann, x50, RV, ext. (sp. no. 1181, horizon MV1)

1) E. afghanistanensis, x40, RV, int. (sp. no. 1215, horizon MV4), female

m) E. afghanistanensis, x 50, LV, ext. (sp. no. 1151, horizon MV1)

n) E. afghanistanensis, x45, LV, int. (sp. no. 1244, horizon MV8), male

o) E. afghanistanensis, x36, LV, ext. (sp. no. 1235 , horizon MV7)

p) E. afghanistanensis, x45, LV, int. (sp. no. 1234, horizon MV7)

q) E. cf. afghanistanensis, x79, LV, ext. (sp. no. 1183, horizon MV1)

r) E. cf. afghanistanènsis, x62, LV, ext. (sp. no. 1257 , horizon MV9)

s) E. cf. afghanistanensis, x56, LV, ext. (sp. no. 1214 , horizon MV4)

t) Candona candita (O.F. MUELLER), x55, carapace, ext (sp. no. 1186, horizon MV1)

$\mathrm{LV}=$ left valve, $\mathrm{RV}=$ right valve, ext. = external view, int = internal view

\section{PLATE 2: Chara globularis THULLIER}

a) gyrogonite, $x 70$, apex lacking, lateral view (sp. no. 1212, horizon MV3)

b) gyrogonite, x60, lateral view (sp. no. 1220 , horizon MV4)

c) gyrogonite, x63, lateral view (sp. no. 1224 , horizon MV4)

d) oospore, x80, lateral view (sp. no. 1233, horizon MV5)

e) gyrogonite with protruding apex, $x 56$, lateral view (sp. no. 1231, horizon MV5)

f) oospore $\mathrm{x} 89$, lateral view (sp. no. 1221, horizon MV4)

g) oospore, x111, semi apical view (sp. no. 1222, horizon MV4)

h) oospore, x 170, semi basal view (sp. no. 1254 , horizon MV8)

i) gyrogonite, x82, apical view (sp. no. 1223 , horizon MV4)

j) gyrogonite, x80, apical view (sp. no. 1219 , horizon MV4)

k) gyrogonite, x114, apical view (sp. no. 1232 , horizon MV5)

1) oospore, $x 55$, lateral view (sp. no. 1189 , horizon MV1)

m) oospore, $x 88$, lateral view (sp. no. 1188 , horizon MV1)

n) oospore, $x 60$, lateral view (sp. no. 1192 , horizon MV1)

o) oospore with protruding apex, $\mathrm{x} 96$, lateral view (sp. no. 1190, horizon MV1)

p) oospore, x64, lateral view (sp. no. 1209, horizon MV2) 
Plate 1
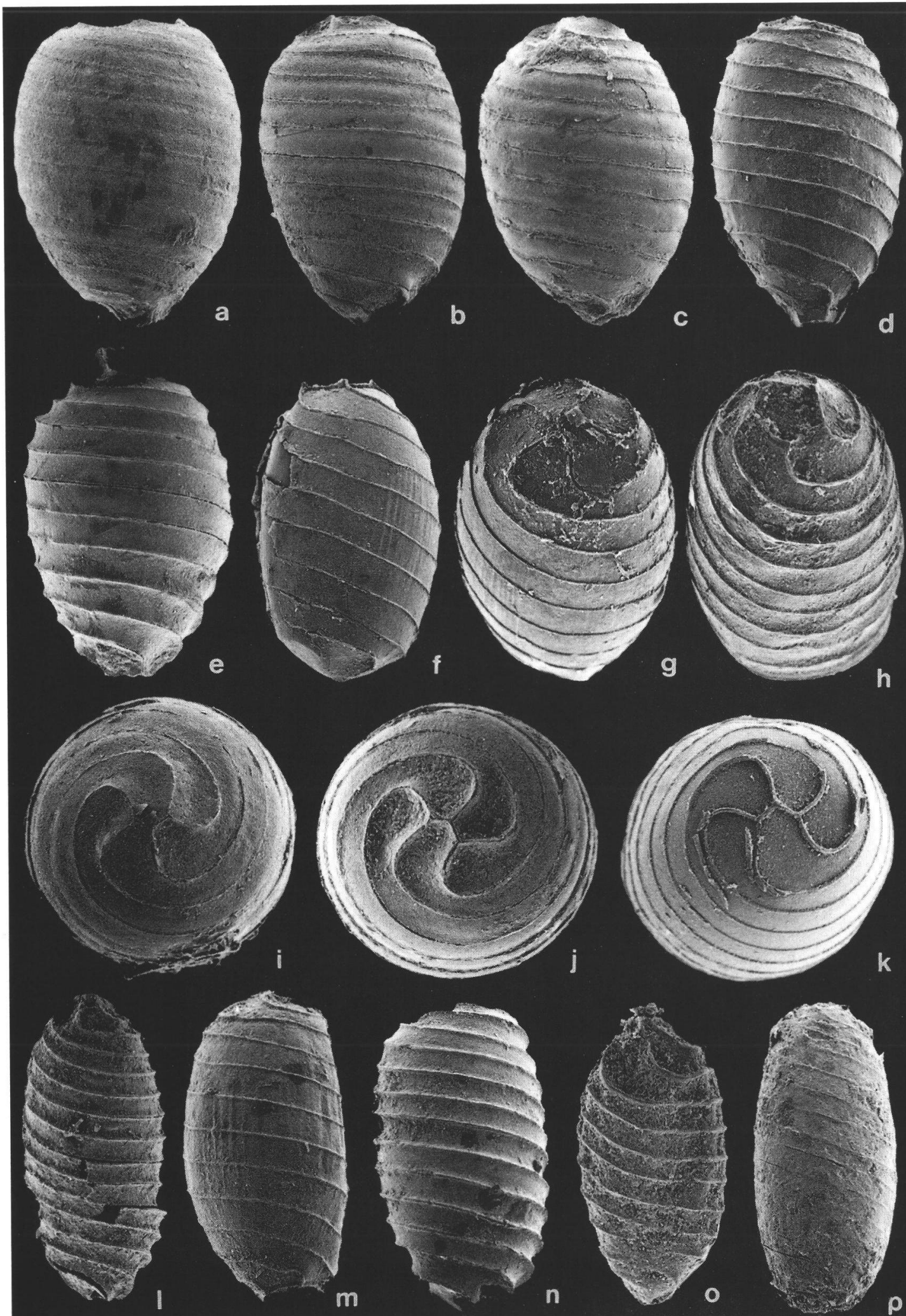
Plate 2

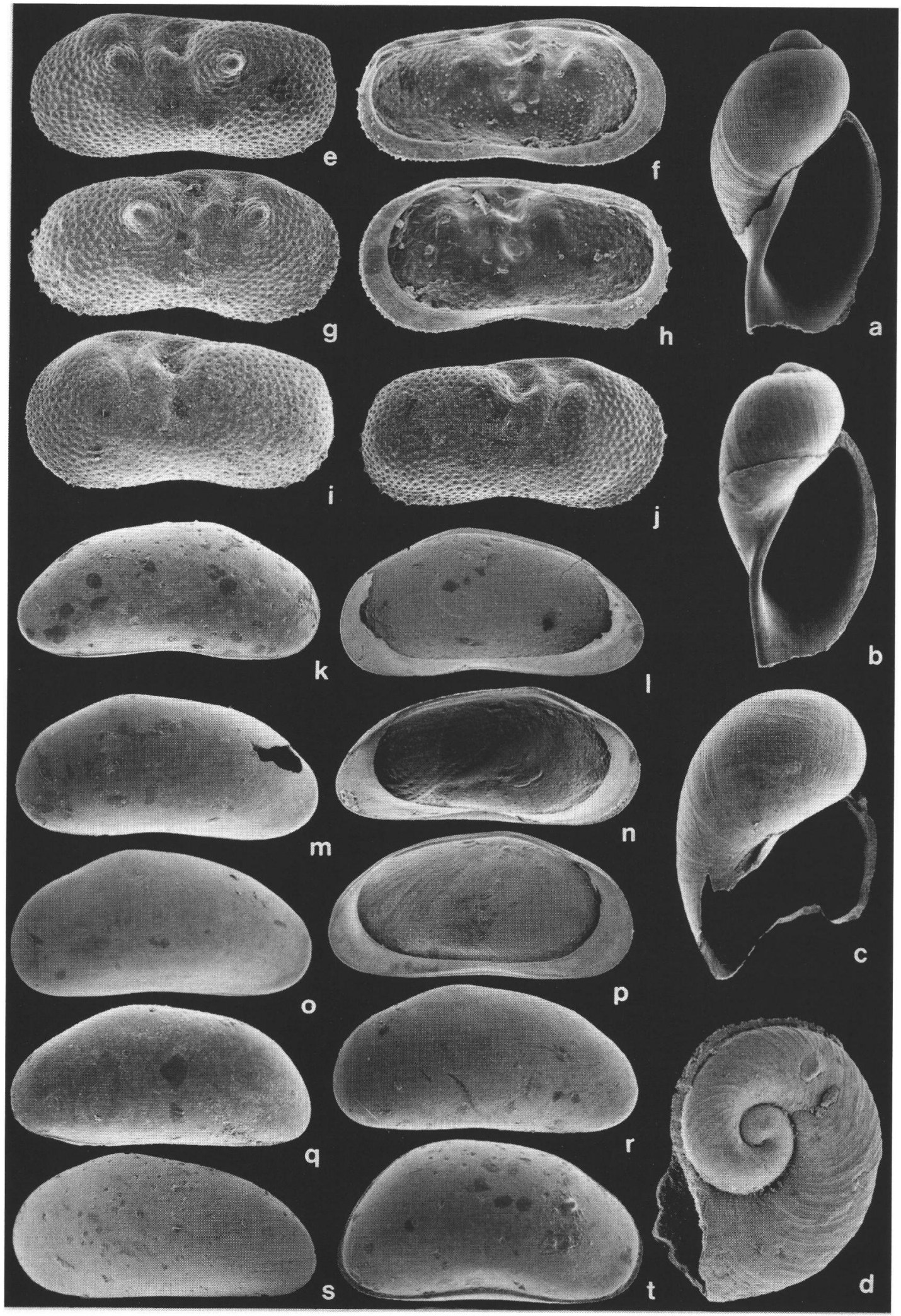

